Tér és Társadalom 20. évf. 2006/4. 169-182. p.

Tér és Társadalom

XX. évf. 2006 4: 169-182

\title{
KITEKINTŐ
}

\section{TERÜLETI EGYENLÖTLENSÉGEK EURÓPÁBAN. A BŐVÍTÉS MINT A KOHÉZIÓ PRÓBÁJA}

\author{
(Territorial Inequalities in Europe Cohesion to the Test \\ of Enlargement)
}

\section{MARIE-CLAUDE MAUREL ${ }^{1}$}

Kulcsszavak:

Európai Unió bövités területi egyenlốtlenségek kohézió

A terjeszkedés az európai kontinens területi ujjraformálásához vezetett. A régi és új tagországok között fennálló tartós fejlettségbeli különbség veszélyeztetheti a gazdasági és társadalmi kohézió-politikát.

A cikk megvizsgál néhany következményt a megnövekedett Európa térbeli szerkezetének szemszögéböl: a belsó és külsö határoknál megjelenö gazdasági egyenlötlenség, a központ-periféria viszonylagos stabilitása, valamint a területi jövedelemegyenlôtlenségek.

Az európai integrációs folyamat következményeképpen nemzeti szinten számíthatunk gazdasági konvergenciára csakúgy, mint Kelet-Közép Európán belüli megnövekedett területi különbségekre. A fôvarosi régiók és a nyugati határrégiók a versenyképesség vezetôi, amig a régi ipari központok és a vidéki keleti perifériák ki vannak téve a gyenge gazdasági növekedésnek és a munkanélküliségnek.

Gazdasági konvergencia vagy széttartás, társadalmi integráció vagy kizárás? Az európai kohéziós politika úgy tünik, vízválasztóhozérkezett.

\section{Bevezetés}

2004 májusában az Európai Unió térképe jelentősen megváltozott. A bővítés az európai kontinens átformálásához vezetett; ami nem csupán geopolitikai hatásokkal bír, hanem jelentôs gazdasági és szociális szerepet is tulajdonítanak neki. A tíz új tagország csatlakozása a Közösség területét $22,5 \%$-al, a lakosság számát 19,4\%-al növelte meg, a GDP azonban csak 4,5\%-al emelkedett. A rendelkezésre álló adatok megmutatják a régi tagországok (EU 15) és a 2004-ben csatlakozott országok életszínvonalának eltérését; a 2004-ben csatlakozott országokban az egy lakosra jutó érték 2,5-szer elmarad a régi tagországok mögött. Ez nagy kihívást jelent a gazdasági és szociális kohézió területén a megnövekedett Európában. A 2004-es bővítést - a Közös Piac 1957. évi alapítása óta az ötödiket - követő gazdasági különbségek növekedése önmagában nem új a Közösség számára. Az elsỏ bővítések azokat az országokat érintették, melyek gazdasági fejlettségi szintje a csatlakozásuk időpontjában a közösségi átlag alatt volt. Ezek a gazdasági különbségek tették fontossá egy olyan szolidáris politika bevezetését a tagországok körében, mely lehetőséget ad a strukturális egyenlőtlenségek csökkentésére. Ez az európai újjáépítési politika egyik 
eredeti dimenziója, mely a gazdasági és szociális kohéziós politika segítségével képes figylemmel követni a változások liberalizálódását.

Az Európai Unió keleti terjeszkedése okozza a mély és komplex területi változásokat. A gazdasági és szociális különbségek jelentős hatást gyakorolnak a megnövekedett Unió (EU 25) területén. Ez a tény felveti egy új kohéziós politika kialakításának kérdését. Ha a gazdasági prosperitás terén fennálló különbségek elkülönítik egymástól a régi és az újonnan csatlakozott tagországokat, a fejlödésben lemaradt területek előrehaladása érdekében a tagországoknak kölcsönösen lépéseket kell tenniük. Ez leginkább a megnövelt pénzügyi segítségnyújtásban nyilvánul meg, ami feszültségforrás lehet a tagországok között a 2007-2013-as periódusra vonatkozó pénzügyi források elosztásakor. Nem a költségvetési probléma az egyetlen olyan szempont, amelyet figyelembe kell venni az olyan politikai döntések meghozatalánál, melyek hatással vannak a kohéziós politika jövőjére.

Jelen tanulmány célja megvilágítani a lehetséges veszélyeket, valamint a felvázolt helyzet következményeit: kezdve az európai kontinens gazdasági egyenlötlenségeinek megállapításával és a megnövekedett Európa területi egyenlőtlenségének növekedésének bemutatásával. Az új tagállamok csatlakozása miatti területi dinamikák kedveznek majd a gazdasági konvergenciának anélkül, hogy gyöngítenék a szociális és területi kohéziót? Hogyan tudja majd az Unió összhangba hozni a versenyképességi elöírásokat és a kohéziós problémákat, illetve milyen áron fogadja el a megújult szolidaritás kihívását?

\section{A megnövekedett Európa területi újrarendezése}

\section{Gazdasági egyenlötlenségek}

Az európai tér változatos és heterogén terület, melynek oka többek között a történelem során a hatalmi befolyások gyakori váltása. A területek jellegét meghatározó különbségeket nem lehet egyértelmüen egyenlötlenségnek tekinteni. Mindezek a tények egy olyan összehasonlító megközelítés megszületését tették lehetövé, mely világossá teszi a már elvégzett megfigyelések eredményeit. A különbségeket területi vonatkozásukban határozzák meg. Ha megváltoztatjuk egy térbeli eloszlás megfigyelésének a fókuszpontját, megváltozik annak struktúrája, és heterogénebbé válik, amint növekszik az elemzés mértéke. Ez leginkább többlépcsős területi elemzés készítésénél fontos; nemzetközi, nemzeti, regionális és helyi szintek egyidejü elemzésénél. Fontos megemlíteni azonban, hogy ezek a szintek egy politikaiközigazgatási területi felosztás eredményei. Jelen tanulmány arra törekszik, hogy különbözö területi viszonylatban szemlélje a gazdasági és szociális különbségeket, mely viszonylatok különösen fontosak az Unió számára a területi különbségek csökkentésében és a belső kohézió erösítésében. A megfigyelés nem korlátozódhat le a megnövekedett Unió (EU25) területére, mivel két újabb ország (Románia és Bulgária) csatlakozott 2007-ben, két másik országgal pedig megindultak a csatlakozási tárgyalások 2005-ben (Horvátország és Törökország), és mivel néhány ország 
valószínüleg felkérést kap majd az Unió „szomszédos országává” válásra. Az európai kontinensen ezek a területi dinamika meghatározó elemei.

A gazdasági fejlődés területén mutatkozó fő kontrasztok megmutatására készítettek egy elemzést az egy fỏre jutó GDP alapján - vásárlóerő paritáson, dollárban -. Egyszerre vették figyelembe az országok gazdasági mutatóját és a két szomszédos ország értékei közötti különbséget. A szomszédos országok között csak a legerősebb értékeket tartották meg és vizsgálták a határszéli területek tekintetében. A gazdasági egyenlőtlenséget - az európai térdarabolódás legerősebb szereplöjét - így határai mentén jelenítették meg.

\section{1. ÁBRA}

Gazdasági fejlettségi törések

(Economic Discontinuities)

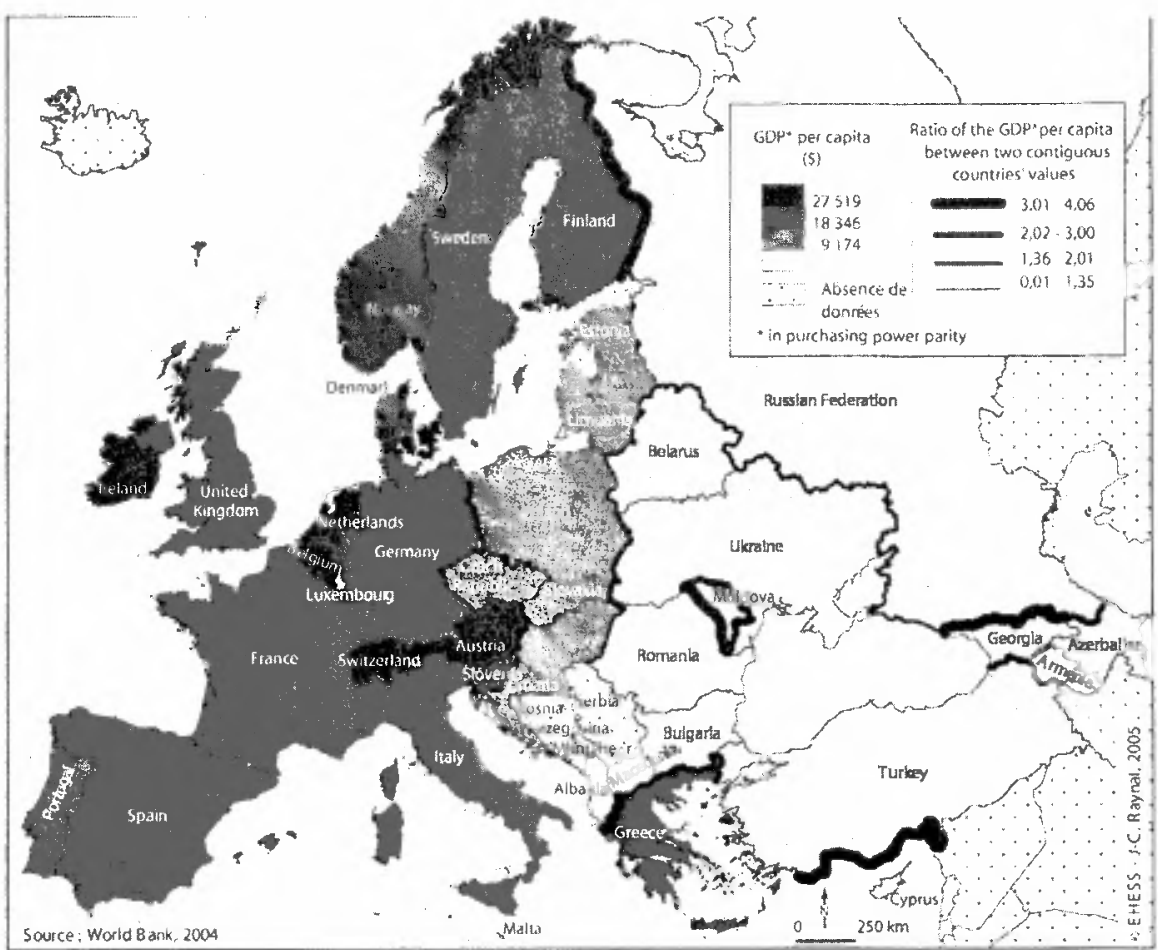

Forrás: World Bank 2004.

$\mathrm{Az}$ így keletkezett kép megkövetel néhány hozzáfüznivalót. Ebben a viszonylatban fennmarad egy egységesen fejlett kép Nyugat-Európa gazdaságáról, ami KeletEurópa és Oroszország felé haladva folyamatosan gyengül, pihenőt tartva KözépEurópában és a Balkánon. Meg kell jegyezni, hogy a legmagasabb érték Norvégié és Svájcé, azé a két országé, akik nem szeretnének belépni az Unióba. Az EU 15-ök mellett néhány periferikus tagország, Spanyolország, Portugália és Görögország - a 
4 kohéziós államból 3 - még mindig gyengébb fejlettségi szintet mutat, míg Î́rország az egy före jutó értékeivel csatlakozott a vezetö csoporthoz.

A legszembetűnőbb adatok azonban a gazdasági egyenlőtlenségre vonatkoznak. A legjelentösebb különbségek a következő országok között figyelhetőek meg: Finnország - 1995 óta EU tag - és Oroszország között - az egy före jutó GDP aránya egy beszámoló szerint 1:3,2 -; valamint összehasonlító szinten mutatja meg a Németország és Lengyelország, Csehország; az Ausztria és Szlovákia, Magyarország, Csehország és a Görögország és Albánia, Törökország, Bulgária közötti különbségeket. Meg kell jegyezni, hogy ezek a különbségek megegyeznek a Vasfüggöny korában tapasztaltakkal. Németország - a fal ledöntése után nem sokkal bekövetkezett újraegyesítése nem vonta maga után az országban található belső (társadalmigazdasági) határok eltủnését.

Egy második, nagyon erős különbségeket határoló vonal az új, közép-európai és balti EU tagállamok keleti (Fehéroroszország, Ukrajna, Moldova) és déli (Balkán) szomszédságában jelenik meg. Abszolút értéken az egy före jutó értékbeli különbségek jóval nagyobbak, mint Nyugat- és Közép-Európa között, habár az egy före jutó GDP aránya egy beszámoló szerint 1:2 (Lengyelország és Ukrajna között), míg Magyarország vagy Szlovákia, valamint Ukrajna között, ahol ez a különbség több mint 2,5-szeres.

Így a nyolc közép-európai és balti 2004-ben csatlakozott EU tagállam átmeneti helyzetben találja magát az EU 15-ök külső határa (ami 2004 májusa óta belső határrá vált) és az EU 25-ök új keleti határai között. A nagy kiterjedésủ gazdasági egyenlőtlenségek körülzárják a volt szocialista blokkot, legalább annyira nyugatról, mint keletről. Ez a térbeli eloszlás megsziládrdítani látszik azt, amit az ellenséges politikai rendszerek eredményeztek az elmúlt évtizedekben; az európai gazdasági tér struktúrája többnyire megmaradt. Az Unió belső és külső határai mentén megfigyelhető, hasonlóan jelentős fejlettségbeli különbségek ráirányítják a figyelmet ezekre az egyenlőtlenségekre; melyek idő- és funkcióbeli, valamint a határok igazgatási módjával kapcsolatos egyenlőtlenségek.

A területi növekedés csökkentette az EU belső határainak funkcióit. A határok állapota folyamatosan javul, és az új tagok is csatlakoznak a schengen-i megállapodáshoz. A Közös Piac területén végbemenő integráció megváltoztatja a forgalmi és kereskedelmi feltételeket a tagországok között. A szomszédos országok határainak átjárhatósága egyre növekszik. Eközben a létező gazdasági különbségek nem tủnnek el, és továbbra is konzerválják a jelentős fejlödésbeli különbségeket (GDP, bérek, életszínvonal stb.). A munkaeró, javak és tőke ellentétes irányú mozgatásával ezek a különbségek hasznosíthatóakká válnak. Ezek közül néhány hozzájárul a határ menti térségekben megfigyelhető feszültség erỏsítéséhez, mely időről időre hosszabb vagy rövidebb távon - erösíti a konvergenciát. Az így mủködő területek újraminősítése - amikor azok átjárhatóvá válnak - kiegészítő funkciókkal látja azt el, támogatva az integrációt és a gazdasági versenyképességük erösítését.

Ezek a változások az EU külső határainak kiterjesztéséből is erednek, melyek pillanatnyilag Közép-Európa és Európa balti részének keleti határán helyezkednek el. 
Ez a változás a stratégiai és katonai funkciók megerősítését, a javak áramlásának kontrollját és a migráció fokozott ellenörzését vonja maga után. Költséges változások árán sikerült eltávolítani a kommunista rendszerek maradványait, melynek eredményeképpen a közép- és balti európai államok jelentős gazdasági fejlödést értek el a kilencvenes évek közepe óta, azokhoz a keletebbre fekvő országokhoz képest, ahol a reformokat lassították vagy megakadályozták az elégedetlenkedések. $\mathrm{Az}$ ex-kommunista blokk országaiban a rendszerváltás folyamata egyenlőtlenül zajlott le, ahol a gyengülésért felelős legfontosabb tényező az egyenlőtlen gazdasági helyzet volt. Az EU keleti határain megjelenỏ gazdasági különbségek potenciális törésvonalat képeznek az európai kontinensen.

A területi különbségek csökkenésében meghatározó szereppel bír az EU belsö határainak szerepváltozása és átjárhatósága, valamint a külső határok változása. A külső és belsö határok mentén végbemenó mechanizmusok megjelenésének elméletét felelevenítendö: a területi gyarapodás maga után vonja a határ menti terủleteken megjelenő konvergenciát, míg a kontroll megerösítése eltérést nem eredményez. Ha rövid és hosszú távon megfigyelhetöek hasonló hatások, a közép-európai területek belső kohézióját fenyegethetik az ellentétes hatások. Magyarország példáján megfigyelhető - melynek nyugati határai a virágzó gazdaságú Ausztriával szomszédosak, keleti határain a tönkretett gazdaságú Ukrajnával, délen Szerbiával szomszédos -, mely különbségek hatnak a magyar térre.

A nyugati, keleti és délkeleti határok mentén a javuló átjárhatóság és a korlátozások csökkentése olyan folyamatok, melyek nagyban kihatnak a régiók fejlödésére. Az új (2004-es csatlakozással kialakult új határok) tagországok keleti határai mentén fekvő területek potenciális feszültségövezetet képeznek.

\section{Centrum/periféria egyenlötlenség}

A folyamatos növekedés olyan földrajzi jelleget ölt, amely az EU területi növekedésén túl a területi fejlődési irányokban is változást jelent. A déli és északi terjeszkedés után az EU kelet felé tekint. Ez mennyiben változtatja meg a területi egyenlötlenségeket?

Az új gyártók és fogyasztók egy kb. 450 millió lakosú piacra való belépése a termelés és értékesítés újraszervezésével jár együtt. A konkurencia színrelépésével a közös piac progresszív realizálása aktív tényezőjévé válik a területi újrarendezésnek (úgy a régi, mint az új tagországokban). Egy kereskedelmi szempontból nyitott európai térben az újrakonfiguráció pozitív területi változásokat, relatív közelségi és távolsági játszmákat, és a területek gazdaságai és társadalmai közti interakciót eredményez. Az átalakulások felvázolásához - melyek alapja a területi növekedés - megpróbáljuk megbecsülni azok területi egyenlötlenségekre és különbségekre kifejtett hatását.

Az Európai Unió területi struktúrája a centrum-periféria modell felidézésével sematizálható. A lakosság koncentrációja, a gazdagság, a globális gazdasági funkciók polarizációja és a kommunikációs infrastruktúra egy központi területen tünik meghatározónak. A „Pentagon” nevü - mivel a formája egy sokszöget ír le, melynek 
csúcsai London, Párizs, München, Milánó és Hamburg irányába mutatnak - központi terület népsürüsége, elérhetősége és attraktivitása szempontjából kiemelkedő. Az európai integráció nyugaton elősegítette a városok fejlödését, a versenyképesség erősödését és a nagyvárosok vonzerejének növekedését.

Ezen központi terület polaritása siettette a terjeszkedést csakúgy, mint az elözőeket. A kisebb népsürüségủ és gyengébb GDP/fö eredményt mutató területekre melyek aztán késöbb integrálódtak - vonatkozóan ez éppúgy igaz; mint a későbbiekben a déli peremtől az északiig, most pedig a keletiig. Az EU 15-ök területén a lakosság $41 \%$-a koncentrálódik a teljes terület 18\%-át kitevő területre, mely terület a GDP 49\%-át állítja elö. A 27 tagúvá bövülés gyengítette a lakossági (32\%) és a gazdasági (46,5\%) súlypontot egy, az összterület alig 14\%-át kitevő centrumra. Gazdasági és térbeli vonatkozásban az EU központja még sokáig domináns marad.

Más mutatók kihangsúlyozzák egy olyan területi stratégia hatásait, melyet egy centrum-periféria modell alapján alakítottak ki. A potenciális elérhetőségi indexeket tartalmazó térkép - különbözö közlekedési módokkal - európai régiók viszonylatában számolva (NUTS 3 szinten) megerősíti az említett területi eloszlást. Egy olyan központi tér körül, mely jól ellátott és elérhető, - Liverpooltól Londonig, az Egyesült Királyságtól az észak-olaszországi Milánóig tart, magába foglalja a Benelux államokat, a Rajna-vidéki tengelyt úgy, mint Berlint és Párizst - az elérhetőségi index gyorsan csökken a periféria területei felé haladva. A nagy városi agglomerációk Dublin, Madrid, Barcelona, Róma, Nápoly, Tesszaloniki, Athén, Koppenhága, Malmö, Göteborg - azonban jól elérhetőek (többnyire a nemzetközi repülőtereknek köszönhetỏen). Portugália, Spanyolország, Írország, Skócia, Svédország, Finnország, DélOlaszország és Görögország régiói többségének elérhetősége az európai átlag alatt van. Igaz mindez az újonnan csatlakozott országokra - a fővárosok régiói kivételt képeznek (mindenhol a repülỏterek miatt). Meg kell jegyezni, hogy a tagországok hajlamosak a régivel azonos térbeli struktúrát létrehozni az elérhetőség érdekében, előnyben részesítik a központokat a perifériákhoz képest.

\section{Regionális egyenlötlenségek a megnövekedett Unió területén}

A regionális egyenlőtlenségek kiterjedését és azok fejlödését az Európai Bizottság folyamatosan figyeli, és rendszeresen közzé teszi a gazdasági és szociális kohéziós eredményeket, melyekben a bővítés elötti és utáni beszámolókban közzétett adatokra támaszkodik. A megnövekedett Európa területére ható egyenlötlenségek elemzése problémákat vet fel.

A területi egyenlötlenségeket relatív időtartamban mérik, melyek erősen függnek az öket generáló területi kontextustól, ami őket létrehozza. Ugyanaz az indikátor használatos a fejlődésben megkésett régiók (1. célkitüzés) javára a választhatósági küszöb stabilizálása érdekében. Ez olyan régiókra vonatkozik, ahol az egy före jutó GDP a közösségi átlag 75\%-a alatt van.

A második szakaszról szóló beszámoló nyilvánvalóvá tette, hogy az EU 15-ök teruiletén elindult a különbségek kiegyenlítésének folyamata. „Nagyon tisztán látható 
a különbség Spanyolország, Görögország és Portugália közőtt, ahol az egy före jutó GDP a közösségi átlag 67-82\%-a között van, míg a többi tagországban megegyezik azzal, vagy meg is haladja a közösségi átlagot." Az erős konvergenciának köszönhetően a három ország és a többi EU tag között a különbség a harmadával ugyan csökkent, de a felzárkóztatás hosszú folyamat. Az 1988-1999-es periódusban a régiók közötti gazdasági különbségek csökkentek, de kisebb mértékben, mint az országok közöttiek. A szélsőséges helyzetekben a kontraszt nagyon fontos. A régiók 10\%-a, ahol a legmagasabb a GDP (60\%-kal az átlag fölött) a központi területhez tartozik (korábban definiálva), míg a lista alján lévỏ területek (GDP $40 \%-k a l$ az átlag alatt) a következök: görög régiók, a francia tengerentúli területek, néhány portugál régió és Dél-Olaszország. A tagállamokon belüli regionális különbségek erösek és tartósak, különösen Olaszország, Németország (ahol 1999-ben az átlag 65-70\%-át érték el), Spanyolország és Portugália esetében. Az összehasonlító konklúziókat a szociális kohézió (foglalkoztatottsági és munkanélküliségi ráta) indikátorainak elemzéséböl vonták le. Általában a jelentős fejlödés az EU15-ök területén ment végbe, a különbségek csökkenésében nyilvánultak meg, ami a gazdasági és szociális kohéziós politika eredményessége mellett tanúskodik. Ezek a tanulságok nagyon fontosak a terjeszkedést követö időszakban, mivel a megnövekedett területi különbségek egy kiterjedtebb, kevésbé gazdag és nagyon heterogén területet érintenek.

A Második Kohéziós Jelentés felveti a területi különbségek megduplázódásának lehetőségét, és vizsgálja azt a 27 tagúra növekedett Európai Unióban. Az egy före jutó GDP aránya a leggazdagabb (10\%) és a legszegényebb (10\%) régiók között közel a duplájára növekedett (2,4-röl 5,3-ra). A 12 tagjelölt ország (2004. május 1-jén és 2007. január 1-jén csatlakozottak) felvétele a relatív bevétel szerkezetének és szintjének megváltoztatására szólít fel azoknak a régióknak az esetében, ahol nagyon alacsony az egy före jutó GDP.

A két ország (Bulgária és Románia) 2007-es csatlakozásának halogatásával (ahol az egy före jutó GDP a közösségi átlag 25\%-a), az EU az egymást gyorsan követő terjeszkedések kohéziós politikára gyakorolt hatását mutatta meg. Ez több szabályozást jelent, de nem kizárólag az új tagállamokra vonatkozóan.

A Harmadik Kohéziós Jelentés, melyet a nagy bővítés előestéjén publikáltak, megerösíti az EU-n belüli területi különbségek növekedését. Ezek alapján a jelentés három csoportot képez a tagállamokból: a felsó csoportba 12 régi tagország tartozik, ahol a GDP a közösségi átlag fölött van, a középső csoportba tartozik Spanyolország, Portugália, Görögország, Ciprus, Szlovénia, Csehország és Málta, a harmadik csoportba pedig a többi új tagország. A régiók közötti különbségek egyre mélyülnek. Egyre nő azon lakosok száma, akik olyan régióban élnek, ahol a GDP a közösségi átlag 75\%-a alatt van. Ez 73 millió fó az EU15-ök területén (a teljes lakosság 19\%-a), 123 millió fö az EU25-ök területén (a lakosság 27\%-a) és 153 millió fö az EU27-ek területén (a teljes lakosság 32\%-a). Az említett lakosság kétharmada az új tagállamok területén él. 
Az egy före jutó GDP átlagos értékének csökkenésével, a 15-ről 25 tagországra való növekedés felelös egy olyan statisztikai hatásért, ami minden területi egység relatív pozícióját megváltoztatja. Néhány régió ebböl profitált - különösen DélEurópában -, mivel átlépte a 75\%-os felső határt az EU 25 tagúra való bővülésével. A jövőben a kedvezményezetti helyzetüket meg kell szüntetni. Ennek a statisztikai hatásnak a következménye körülbelül 14 régióra és 19 millió lakosra vonatkozik. A tét nagyon fontos, különösen a kohéziós országok (Spanyolország, Portugália, Görögország) számára, de Németország és az Egyesült Királyság számára is, ahol szintén vannak érintett területek.

Ha a gazdasági különbségeket nem tudják megbecsülni, a változásuk ijesztő politikai ítéleteket von majd magával a Strukturális Alapok újraelosztásánál. A szegényebb Közép-, és Kelet-Európa felé való terjeszkedés a különbségek újrakonfigurációjával jár, ami a Strukturális Alapok újrakiegyenlítését kell, hogy jelentse közép-, és hosszú távon egyaránt; ha az Unió hủséges akar maradni a szolidaritási alapelvéhez. Ezek a legfontosabb összetevői a 2006 utáni kohéziós politikáról szóló vitának.

\section{Az új tagállamok és a kohézió kihívása}

A közép-európai és balti államok integrációja kihívások elé állítja az európai kohéziót. A gazdasági, szociális és területi dimenziók, mint az európai politika kulcsfogalmai, kölcsönhatásban állnak egymással. Nagy a kockázat, látva, hogy a gazdasági különbségek szociális különbségekké válnak, lehetőséget adván a szociális kirekesztésre és területi szétdarabolásra. Itt az idő, hogy megakadályozzuk a negatív hatásokat.

Elöször a gazdasági növekedés dinamikáját elemezzük, az államok és régiók szintjén lévö modalitás és konvergencia körülményeinek feltárása céljából. Másodsorban kimutatjuk, hogy a munkapiacon érzékelhetö regionális mozgási pályákon tapasztalható eltérés nem elhanyagolható kockázatot eredményez: néhány terület és társadalmi réteg tartós leszakadását.

\section{Gazdasági konvergencia és európai integráció}

A nyolc közép-európai és balti ország csatlakozása (2004) újra felveti a gazdasági felzárkóztatás kérdését. Az egy főre jutó GDP tekintetében ezek az új tagok sokkal nagyobb lemaradásban vannak, mint a déliek a csatlakozás idején. Az egy före jutó különbségek jelentösek nemzeti szinten, de még inkább regionális viszonylatban. Szlovákia megközelíti az EU25-ök átlagának 75\%-át, míg Lettország, Litvánia és Észtország esetében ez az arány $36,6 \%, 40,8 \%$ és $42,3 \%$ az EU átlaghoz viszonyítva. Románia és Bulgária még ennél is nagyobb lemaradást produkál. A nemzeti szint alatti különbségek sokkal erősebbek, mint az érintett országok között létezőek. Lengyelországban, Magyarországon és Szlovákiában az Unió keleti határán fekvő legszegényebb régiók az európai átlag 31-37\%-át érik csupán el. Ha a regionális különbségeket európai szinten mérik, azokat országos szinten is meg lehet tenni. 
A már elkészült ábrázolások figyelembe veszik a területi szinteket, melyek sokkal jobban kifejezik a konkrét szituációt.

Az EU25-ökhöz viszonyított fejlettségre a nyugat-keleti lejtö rányomja a bélyegét. A közép-európai országok legmagasabb egy före jutó GDP értékei a nyugati területeken találhatóak és kelet felé csökkennek. Egyedül a fövárosok régiói érnek el magasabb szintet (az indexek: 148-Prága, 111-Pozsony, 89-Budapest), megzavarva a nyugat-keleti fokozatos csökkenést.

Lengyelországban és Magyarországon a regionális ellentétek sokkal erőteljesebbek, mint Csehországban vagy Szlovákiában. Ezekben az országokban a gazdasági jólét mutatója tanúsítja, hogy a gazdasági fejlettség egyrészt a külföldi befektetők számára vonzó, a fővárosi és a nagyvárosok régióiban (Poznan, Katiwice, Wroclaw, Gdansk) polarizálódik, másrészt pedig az EU határai mellett fekvő régiókban (Délnyugat-Csehország, Nyugat-Dunántúl, Nyugat-Szlovákia). Mindenestre NyugatPomeránia és Lengyelország Lubusz régiója, Északnyugat-Csehország, a keleti német tartományok három határos régiója nincsenek összehasonlítható helyzetben.

A tagjelölt országokban a növekedés a kilencvenes évek közepétől indult útnak és a GDP növekedése az 1994-2001-es időszakban állandósult évi 4\%-ban (Harmadik Jelentés). Bulgária és főleg Románia kivételével a tagjelölt országok régióinak többségében az egy före jutó GDP úgy tủnt, gyorsabban növekszik, mint a kohéziós országok régióiban. Minden tagjelölt országban a GDP növekedésében nyújtott legjobb teljesítményt (1995-2001) a fỏvárosok régiói érték el, már ekkor hozzájárulva a területi egyenlőtlenségek erősítéséhez. A piacgazdasággá való átalakulás segítette a különböző tevékenységek polarizálódását. A növekedési modell az agglomerációs externáliákon és a hatékonyságon alapszik. A régiók adaptációs készsége az új versenyelönyök irányában különösen differenciálódik. A transznacionális vállalatok az olyan tényezőket veszik figyelembe, mint megközelíthetőség és a piacokhoz való közelség, a munkaerő ára, minősége, képzettsége stb. Ebben a megnövekedett európai térben a munkamegosztás folyamatát a transznacionális vállalatok szervezik, akik ebben a tevékenységük racionalizálásának lehetőségét látják. Az implementációs stratégiáikban a közvetlen külföldi befektetők előnyben részesítik a komparatív előnyök szempontjából leginkább pozícionált helyeket.

A csatlakozó országok esetében ez a folyamat strukturálisan különböző gazdaságokban ment végbe; olyanokban, amelyek már véghezvittek egy munkapiaci átalakítást. Az elindított újrastrukturálás a munkapiac gyengülését vonta maga után. A tagjelölt országokban a munkapiac a gazdaság gyenge pontja maradt. Gyenge alkalmazási ráta jellemzi, mely az Európai Tanács által 2005-re kitüzött 67\%-os céltól (2001. március) elmarad.

Ez főleg azokra a területekre jellemzö, melyeket elért a munkanélküliség és továbbra is meghatározó maradt. Az új tagországokban a munkanélküliségi ráta 2003-ban elérte a 14,5\%-ot (szemben az EU 15-ök 8,1\%-val), nagy különbséget mutatván e tekintetben az országok és régiók között. A tíz legmagasabb munkanélküliségi rátával küszködő európai régió közül öt Lengyelországban és egy Szlovákiában helyezkedik el. Összevetve a szorult költségvetési helyzettel, a poszt- 
kommunista kormányok szakítottak a szolidaritási szociális politikájukkal. Ezen tettükkel igazolták a munkanélküliség gyenge mértékü kártalanítását, a közszolgáltatásokra fordított kevés figyelmet. Áttérve a gazdasági liberalizmusra, ezek az országok olyan szociális modellek felé fordultak, melyeket a nagy nemzetközi szervezetek (Nemzetközi Monetáris Alap, Világbank) ajánlottak. A gazdasági konvergencia célja annyira megelózte a szociális kohézióét, hogy az új tagok társadalmai nagyon egyenlötlenül fejlödtek. A nemzeti szintủ területi egyensúlyban bekövetkezett változások megítéléséhez figyelembe kell venni a regionális eltéréseket és azok munkaeröpiacra kifejtett hatásait.

\section{A regionális mozgási pályák eltérése}

Négy különbözö regionális munkaeröpiaci mozgási pályatípust lehet megkülönböztetni. Az első kettőnél jelentős dinamizmus figyelhető meg (nagyvárosok és nyugati régiók), míg a másik két típus (régi ipari területek és vidéki perifériák) krízis helyzetben van vagy hanyatlik, folyamatosan romló foglalkoztatottsági eredményt produkálva.

A teljesítmény a nagyvárosok esetében a legjobb. Összekapcsolják a döntéspólus, a nagy ipari központ és az ütőkártyáik (elérhetöség, attraktivitás, felvevőképesség) funkcióit. A közép-európai fövárosok - a nagy közlekedési folyosókon való fekvésük és nemzetközi repülőtereik miatt - jól megközelíthetöek. Jó belépési pontot jelentenek a nemzetközi piacokra, olyat, ahová a külföldi befektetők terjeszkedni szeretnének. A nagyvárosoknak sok előnye van: a munkaerö mennyisége és minösége (magasan képzett munkaerö), $\mathrm{K}+\mathrm{F}$ lehetőségek koncentrációja, valamint olyan intézmények közelsége, melyek minimálisra csökkentik a piacra jutás költségét. A nagyvárosok a kulcspontjai a külföldi befektetések fogadásának, a multinacionális vállalatok szociális bázisai biztosítása mellett a know-how-k és az innováció vektorok szétterjedésének. Az átalakulás évtizedében a fỏvárosok régióinak teljesítménye volt a legjobb: a szolgáltatási szektorban a foglalkoztatottság jelentős növekedése, jól képzett munkaerỏ és magasabb bérek, pozitív vándorlási mérleg és jóval az országos átlag alatt lévő munkanélküliségi ráta.

Elmondható, hogy az új tagok nyugati régióiban kedvezőek a munkapiaci feltételek. Az EU15-ök határának relatív kỏzelsége és a munkaeröbeli árkülönbözet megerósítette a határ menti kereskedelmi forgalmat (kiskereskedelem, turizmus) és a delokalizációt. Ezeket a régiókat a közvetlen külföldi befektetök elsőként választották ki, hogy bevezethessék az ipari és a szolgáltatási tevékenységeiket. Ezeken a helyeken manapság a munkaerőstruktúra eléggé változatos, a többségét az ipar és a szolgáltatói szektor biztosítja. A munkanélküliségi ráta $20 \%$ fölött van Lengyelország három nyugati határ menti régiójában, ami leginkább a 25 év alatti fiatalokat sújtja (1:2 arányban). Lengyelország azon nyugati régióiban, ahol a természetes szaporulat és a vándorlási egyenleg pozitív, a helyzet az ellenkezője a fent említettnek.

A harmadik típusú mozgási pálya azokra a régi ipari régiókra vonatkozik, melyeket komolyan érintett az átalakulás. Az ipari munkaerő túlsúlya, a hagyományos 
iparágakban a nyersanyagok (vas, vegyészet) jelentős túlsúlya, az új technológiák és a gyenge termelékenység radikális újrastrukturálásra szólítottak fel. Az 1990-es évek vége óta az ipari régiókban mély és tartós krízis figyelhető meg, melyet részlegbezárások és emelkedő munkanélküliség kísértek. Minden olyan régió, ahol a nehézipar dominált, nehézségekbe ütközött. Figyelembe véve a környezet folyamatos hanyatlását, nem sikerült új munkalehetőségeket teremteni és új tevékenységeket a régióba vonzani. A magas munkanélkuuliségi ráta (különösen a tartós munkanélküliség) megnehezíti az alulkvalifikált munkaerő reintegrálását. Lengyelországban, Nyugat-Sziléziában és Sziléziában, Csehországban, Csehország északnyugati és északkeleti részén és Észak-Magyarországon figyelhetjük meg a demográfiai és gazdasági hanyatlás nyomait.

A mozgási pályák utolsó típusa egyenként sorra veszi azokat a rurális perifériákat, melyek strukturális hátrányai azért is nagyobbak, mivel a fejlett Európa keleti határain helyezkednek el. A korán urbanizálódó és iparosodó Csehország kivételével a közép-európai országokban a vidéki jelleg nagy arányban jelen van: Magyarországon a lakosság 35\%-a, Lengyelországban 38\%-a él vidéken, Szlovákiában ez az arány $42 \%$. Ezek az arányok elérhetik és meghaladhatják az 50\%-ot délkelet Lengyelországban és Szlovákia nyugati részén. Ehhez még hozzájárul az agrárnépesség magas aránya, melyet a szocialista rendszer urbanizációjának nem sikerült megszüntetnie. Ezek a területek elszenvedték az előző évtized strukturális változtatásainak elbizonytalanító hatásait.

Ha egy vidékies teruleten konzerválódik a mezỏgazdaság túlnyomó szerepe, akkor az adott terület egyre kevésbé lesz meghatározó a munkaerő és a bevételek terén. A „de-agrárosodás” (a vidékies területeken a mezőgazdaság szerepének csökkentése) a közép-európai területek, a szociális peremre szorulás egyik összetevője (fekete munka, bevétel csökkenés, elszegényedés, elszigetelődés és szociális normahiány). Ha a mezőgazdasági munkaerő nagy számban csökkenne a magyar Alföldön és Szlovákiában, viszonzásul Lengyelország keleti területein a mezőgazdaságban foglalkoztatottak aránya 30\% fölé ugrana. A létfenntartó funkcióval rendelkező családi gazdaságok fenntartása, és a fiatalok időszakos vagy végleges kivándorlása azt mutatják, hogy nem Lengyelország keleten fekvő régióiban a legmagasabb a munkanélküliségi ráta. Egy idó után a falvak elnéptelenítése tủnt az egyetlen kiútnak a fiatalok számára. A gazdasági tevékenységek bővülésének lehetőségei korlátozottak: új gazdasági tevékenységek bevezetése a kis- és középvállalatok formájában, a mezővárosokban és kisvárosokban történő szolgáltatásfejlesztés, a falusi turizmus, melynek fejlődését visszafogja a rossz elérhetőség, infrastrukturális elmaradottság, a vidéki fiatalok gyenge szervezettsége.

Az ellentétes mozgási pályák hozzájárulnak azoknak a területi egyenlótlenségeknek a kiemeléséhez, melyek megduplázzák a nagy szociális egyenlőtlenségeket. Ezen összefüggéseknek az a célja, hogy kiválasszák a nyertes régiókat, míg mások vesztesek maradnak. A vesztes régiókban a kizárás folyamata a társadalmi rétegek többségére hatással volt, beleértve azon keleti perifériák munkanélküliségét, akik nem alkalmasak átállni más ágazatra. Az új tagországok társadalmai erősen egyen- 
lötlenné váltak, és a területek elvesztették homogenitásukat. Mindegyik országban a gazdasági különbségek és a szociális egyenlőtlenségek közti kapcsolatot tekintik a fó veszélynek, ami a szociális és területi kohéziót fenyegeti. Ez felveti a helyzet megoldására alkalmas területfejlesztési politikák gyakorlati alkalmasságának szükségességét a létező különbségek csökkentése érdekében; a közszolgáltatások elérhetôvé tételével, az alap infrastruktúra és a minimum szociális igazságosság biztosításával.

\section{Konklúzió: Milyen kohéziós politikát kellene követnie a terïleti egyenlötlenségek Európájának?}

A növekedés területi tétjei következtében az európai kohéziós politika történelmének fordulópontjához érkezett. Az Európai Bizottság által közzétett Harmadik Jelentés a Gazdasági és Szociális Kohézióról hangsúlyozza a regionális fejlesztések előnyös hatásait az EU15-ök területén belül létező különbségek csökkentésére. A Bizottság kéri a tagországoktól kohéziós politikájuk felépítésének újragondolását, prioritásaik újrafogalmazását és implementálási rendszerük reformálását. Az összefüggő előterjesztések és érvek eredményre vezetnek-e majd? Egy megreformált kohéziós politika és jelentős szolidáris politika elismerésével és követésével mik lehetnek az Unió kilátásai és ezek hatásai a 2007-2013-as időszakra?

A megnövekedett Európában a centrum-periféria struktúra eléggé stabilnak tủnik. A legalább négy évtizednyi gazdasági és szociális fejlődés eredménye mindez. A „Pentagon” alakzatban megfogalmazott központi térből eredeztethető a kereskedelmi kapitalizmus, ami az innovációs kapacitásából kvázi folyamatosan tudott erőt meríteni. A 20. század ötvenes évei óta motor szerepet játszott az európai szerkezetben, ami ennek a területnek a központiságára támaszkodva felépítette a Közös Piac, majd a CEE gazdasági hatalmát. Az egymást követö bővítések megnyerték az egyre távolabb lévő perifériákat, melyek integrációját jobban irányították, mint a struktúrájukat és a teljesítményüket, ezzel lemaradást okozva a fejlettségben. Az Unió alapító tagjai, mivel összeköti őket a történelmi tapasztalat és a hasonló politikai érdek, döntő szerepet játszottak a szolidaritási célú közösségi újjáépítés sikerében. A kedvezményezett országokkal létrejött szinergia megerösítette a gazdasági és a politikai kapcsolatokat is. A 12 tagország részvétele a gazdasági és monetáris Unióban, köztük a négy kohéziós országgal - adja erre a bizonyítékot.

Az új perifériák Unióba való belépése - melyek fejlődésben való lemaradása jelentős - felveti a szociális-gazdasági felzárkóztatás speciális kérdését. A kohéziós országokban sikerrel megvalósított eseményeket az újonnan csatlakozott országokban be lehet-e vezetni? A kohéziós politika követése és annak kiterjesztése megkívánja a Strukturális Alapok megerösítését és az elosztás újragondolását a fontosság sorrendjében (az új tagországokhoz megy a Strukturális Alapok juttatásainak közel 52\%-a). Az 1988-ban bevezetett politikai elosztás megváltozott a Strukturális Alapok reformjához képest. Több hozzájáruló országban gazdasági növekedés figyelhetö meg, melynek okai inkább strukturálisak, mintsem konjunkturálisak. A 25 tagúvá válás következtében, ami a politikai döntések kapacitását láthatóan csök- 
kentette, elvesztették a politikai befolyásukat. Az európai koncepció - mely a politikai integráción alapszik - kisebbségivé változott. Az új tagországokat egy olyan Unió képével biztatták, ahol a gazdasági integráció, a hatékonyság és a kevésbé intézményesített szabad kereskedelmi zóna helytálló fogalmak. Ahol az Unióról szőtt képek különböznek egymástól, az újraelosztási politikával kapcsolatos elképzelések összeütközhetnek. Nagy a kockázata annak, hogy a nagy európai terv nem más csupán, mint egy különböző gyorsaságú területekkel teli Európán belüli transzfer.

Másrészt a megfigyelt területi különbségek csökkentésére vagy inkább elmélyítésére hívja fel a figyelmet. Konvergencia vagy divergencia? Integráció vagy marginalizáció? Miként dől el, hogy a két lehetőség közül melyiket választják majd? Két elemzési lehetöséget kell számba venni: a területi különbségek nagyságát és a felzárkóztatás hatásait, melyek különbözö területi viszonylatban ellenkezőképpen nyilvánulnak meg. A gazdasági integrációt általában úgy tekintik, mint egy, a konvergenciát és a növekedést elósegítő folyamatot. Az empírikus elemzések ezeket a tendenciákat jóval komplexebbnek mutatják. A megfigyelt konvergencia - a kohéziós országokban, és ez javasolt az új tagországokban is - a regionális egyenlőtlenségek elmélyülését követően kerül elobtérbe. Az integráció erösíti a legjobban pozícionált régiók (az új tagok esetében a nyugati és a fơvárosi régiók) profitorientált tevékenységének polarizálását, mely pozitív hatást fejt ki a nemzetgazdaságok növekedési rátájára. A periféria országainak felzárkóztatása hatással van a nemzeti szint alatti területeken lévő különbségek elönnyé fordítására. Az empírikus elemzések többségéböl az következik, hogy egy gyorsabban végbemenö konvergencia az, amit véghez kellene vinni. Ilyen körülmények között lehetséges-e még olyan kohéziós politikát legitimálni, ami követni tudja a regionális különbségek csökkentését, mint első célkitüzést?

\section{Jegyzet}

${ }^{1}$ Directrice d'études; EHESS, Paris.

\section{Irodalom}

Bachtler, J.-Downes R.-Gorzelak G. (2000) Transition, Cohesion and Regional Policy in Central and Eastern Europe. Aldershot, Ashgate.

Commission européenne (2001) Unité de l'Europe, solidarité des peuples, diversité des territoires, deuxième rapport sur la cohésion économique et sociale. 1. Office des publications officielles des Communautés européennes. Luxembourg.

Commission européenne (2003) Régions: Annuaire statistique 2003. Office des publications officielles des Communautés européennes.

Commission européenne (2004) Un nouveau partenariat pour la cohésion convergence compétitivité coopération Troisième rapport sur la cohésion économique et sociale. http://europa.eu.int.

Drevet, J.F. (2004) L'élargissement de l'Union européenne, Jusqu'où? L'Harmattan, Paris.

Dupuch, S.-Jennequin, H.-Mouhoud El M. (2004) Les incidences de l'élargissement de l'UE sur la géographie économique européenne: les tendances de la spécialisation, - Chavance B. (ed.) Les incertitudes du grand élargissement, L'Europe centrale et balte dans l'intégration européenne. L'Harmattan, Paris. 67-90. o. 
EIB Papers (2000) „What diagnosis for Europe's ailing regions?" - Regional development in Europe: An assessment of policy strategies. Volume $5, \mathrm{n}^{\circ} 1$.

EIB Papers (2000) „A survey of socio-economic disparities between the regions of the EU" in Regional convergence in Europe. Theory and empirical evidence. 5.

ESPON (European Spatial Planning Observation Network) http://www.espon.eu/

Fayolle, J. (2003) Acquis social, acquis communautaire? La solidarité à l'épreuve de l'élargissement, Problèmes économiques. 9-13. o.

Gaubert, N. (2004) Quelle politique de cohésion dans une Europe élargie? Pouvoirs locaux. 61. (http:/www.espacestemps.net/document 613.html)

Grasland, C. (2004) Les inégalités régionales dans une Europe élargie. - Chavance B. (szerk.) Les incertitudes du grand élargissement, L'Europe centrale et balte dans l'intégration européenne., L'Harmattan, Paris. 181-216. o.

Heiderich, M. (2003) Regional inequalities in the enlarged Europe. Journal of European Social Policy. 4. 313-333. o.

Komornicki, T. (2001) Changes in the role and permeability of Polish borders. - Geographia Polonica. 1. 77-100. o.

Lepesant, G. (1998) Géopolitique des frontières orientales de l'Allemagne. Les implications de l'élargissement de l'Union européenne. L'Harmattan, Paris.

Lepesant, G. (2004) Les marges orientales de l'Union européenne à 25. Le courrier des pays de l'Est. 1042. 4-19. o.

Maurel, M.C. (2003) Trajectoires post-socialistes et recomposition des territoires en Europe centrale. Forest M. - Mink G. (ed.) Post-communisme: les sciences sociales à l'épreuve. CEFRES, Prague. 39-53. o.

Maurel, M. C. (2004) L'élargissement à l'Est: une nouvelle donne pour l'Union européenne. Annales de géographie. 636. 115-123. o.

Maurel, M.C. (2004) Différenciation et reconfiguration des territoires en Europe centrale. Annales de géographie. 636, 124-144. 0 .

Maurel, M.C. (2004) Les enjeux des mutations des territoires ruraux : l'improbable convergence vers un modèle agricole européen. - Chavance B. (ed.) Les incertitudes du grand élargissement. L'Europe centrale et balte dans l'intégration européenne. L'Harmattan, Paris, 147-180. o.

Revue géographique de l'Est, Etats et frontières en Europe centrale et orientale, 4/décembre. 1998.

Revue géographique de l'Est. (2003) Permanences et mutations spatiales dans la Hongrie en transition. 1-2. o.

Riou, S. (2003) Géographie, croissance et politique de cohésion en Europe. Revue française d'économie. 3. 